\title{
Developing Lean Manufacturing Based Learning Model to Improve Work Skills of Vocational Students
}

\author{
Suryo Hartanto ${ }^{1, *}$, Zaenal Arifin ${ }^{2}$, Sri Langgeng Ratnasari ${ }^{3}$, Rizky Ema Wulansari ${ }^{4}$, Asrul Huda ${ }^{4}$ \\ ${ }^{1}$ Faculty of Teacher and Training, Universitas Riau Kepulauan, Indonesia \\ ${ }^{2}$ Faculty of Engineering, Universitas Riau Kepulauan, Indonesia \\ ${ }^{3}$ Faculty of Economics, Universitas Riau Kepulauan, Indonesia \\ ${ }^{4}$ Faculty of Engineering, Universitas Negeri Padang, Indonesia
}

Received October 24, 2019; Revised January 21, 2020; Accepted February 25, 2020

Copyright $\mathrm{C} 2020$ by authors, all rights reserved. Authors agree that this article remains permanently open access under the terms of the Creative Commons Attribution License 4.0 International License

\begin{abstract}
The low absorption of the workforce in the vocational high school graduates indicates their lack of expertise and competency. It urges to improve their work skills to meet the demand of work. This research aims at developing a Lean-based learning model to enhance the work skills of vocational high school students. This research categorized as development research uses the modified Borg and Gall method. The Lean-based learning model was tested through three stages, namely its validity, effectiveness and practicality. Respondents of the research are vocational high school students, vocational high school teachers and industry practitioners in Indonesia. The model was validated by some experts and FGD results. The effectiveness of the model was tested by an experimental with a posttest only control group design. The population of the experiment was students of the Vocational High School who were doing an industrial experience in some industries, which followed a work shadowing strategy, the sample is chosen by random sampling; data were collected to develop a performance test. Two questionnaires were used to evaluate the practicability of the model according to the perceptions of the teachers and students of the Vocational High School. Based on the research, the developed learning model can be categorized as "good" in case of its validity, effectiveness, and practicality. It means that the lean-based learning model is valid, effective and practical. The conclusion of research is that lean learning model is one of the alternatives to improve work skills competency among vocational high school students to fulfill the industrial demand.
\end{abstract}

Keywords Work Skills, Lean-based Learning Model, Vocational High School Vocational Hig

\section{Introduction}

The low competency among vocational high students indicates that the learning process has not comprehensively met the aspects of work skills and it makes the graduates lack expertise. Basically, the learning process must be directly integrated with the work process to facilitate the students with a real experience of work setting,(Lubis, 2010)(Palmer, 2007)(Hartanto, 2017). The students' competency skills can be enhanced through the appropriate learning strategies to equip them with knowledge, attitudes, skills and work values which are needed in the real work environment, (Habanabakize \& Pardjono, 2018), (Hartanto et al., 2019). The role of vocational high schools is to prepare individuals to achieve competency skills, sustain individual lives, face the world of work, and develop careers in the future, (Calhoun, Calfrey.C;Finch, 1982), (Hartanto et al., 2019). Therefore, it must produce graduates who are ready to work, smart, competitive and have a strong character as professional workers.

The inadequate competency of vocational graduates can be seen from the labor absorption within the national scale (Indonesia) in which only $10.87 \%$ of vocational graduates. It is lower than other education levels, such as a public high school with $20.52 \%, 18.16 \%$ for junior high school and dominated by elementary level graduates with $42.23 \%$ based on Indonesian Statistical Database, BPS. 2107. This gap must be solved immediately by enhancing the competency among vocational students in order to meet the industrial standard. Therefore, this study aims at developing lean-based learning models referring to industrial needs. In this model, the learning process is integrated with the world of work to present a bridge connecting the school education and the professional work in order to provide real work experience among students. The learning system that integrates the world of work 
provides enormous benefits in the development of vocational competence, (Blum, 2008), (Sousa, 2001), (Estriyanto, 2017). The world of work integration is a form of the environment role to transform the students' competency to achieve sustainable development.

\section{Literature Review}

Work skills are abilities that are needed by individuals in the workplace including hard skills and soft skills. The hard skills in vocational education must be possessed by students to achieve their competencies. It is related to technical procedures and fixed rules that can be learned through the instructional process to gain the intellectual abilities in facing the rapid advancement of information and environment as well as to support the skills development according to the needs of industry and the world of work, (Coates, 2006), (Hartanto, 2017), (Pritchard, 2013). The improvement of hard skills must be supported by soft skills to be all-around workers. The soft skills are abilities possessed by individuals that cannot be seen but it has a big role in social and community life to support their careers and jobs. This ability is also required by companies or the world of work, (Hartanto, 2017), (Majid, Liming, Tong, \& Raihana, 2002), (Robles, 2012). The adequate soft skills will be beneficial for each individual as to how to communicate, listen, make dialogue, provide feedback, work in a team and solve problems, (Chaturvedi, Yadav, \& Bajpai, 2011), (Hartanto \& Fordiana, 2018). The soft skills have a significant impact on hard skills and play a crucial role for students in entering the work setting because it makes them more flexible and have positive thinking to fulfill the industrial expectations in global competition (Mangala Ethaiya Rani, 2010). It means that the work skills must be owned to answer the challenges of the future work in the industry that will eliminate the low-skilled labors since the job description require skills as well as high expertise in the fields of reading, calculation, communication, and problem-solving.

The vocational education must have the transformational principle in accordance with the needs of society and technology. This is one means to prepare students to face work, so this kind of education must be oriented to the future requirement. The vocational education should be able to train the students to socialize with appropriate attitudes within the world of work, adjust to the employment behavior, have an effective transition to enter the job market, possess specific skills and knowledge towards the working setting,(Furham, 2005).

To prepare students to face the world of work, it should be supported with the right learning process by integrating learning with work or industry. One of the appropriate principles is the application of lean systems. Lean manufacturing is a system used in companies and production processes to achieve maximum profits in case of its effectiveness and productivity through continuous development, (Dillon, 1985) (Fagerlind .S Gustavsson, .K, .J, \& Ekberg, 2015), (Hartanto et al., 2019). Lean is a continuous effort to eliminate waste and increase value-added products for customers, (Sundar, Balaji, \& Satheesh Kumar, 2014), (Fagerlind .S et al., 2015). It is called lean because the process must be run using less material, less investment, less inventory, less space and, fewer people (Wilson, 2010). The implementation of lean manufacturing is outlined in five steps by thoroughly analyzing an entire process including value identification, value streams identification, value stream flow creation, pull system application and excellence orientation (Sundar et al., 2014), (Feld, 2001). Meanwhile, the learning model is a plan that is used to form a curriculum or long-term learning plan, design learning materials, and guide the classroom learning process (Joyce, Bruce.R; Weil.M, 2009), (Syahmaidi.E, Hidayat.H, \& Hartanto.S.at.al, 2019). The lean-based learning model provides a solution to realize work skills development among vocational high school students. School learning must be integrated with the world of work to be able to develop knowledge, skills and attitudes in accordance with the objectives of vocational education. Since intelligence and creativity are not genetically determined, and both can be modified by the environment and school (Rukun, 2015), (Sousa, 2001). The effectiveness of vocational education will be achieved if the learning is done with similar condition as the actual work setting (Hartanto et al., 2019), (Lubis, 2010), (Estriyanto, 2017). 


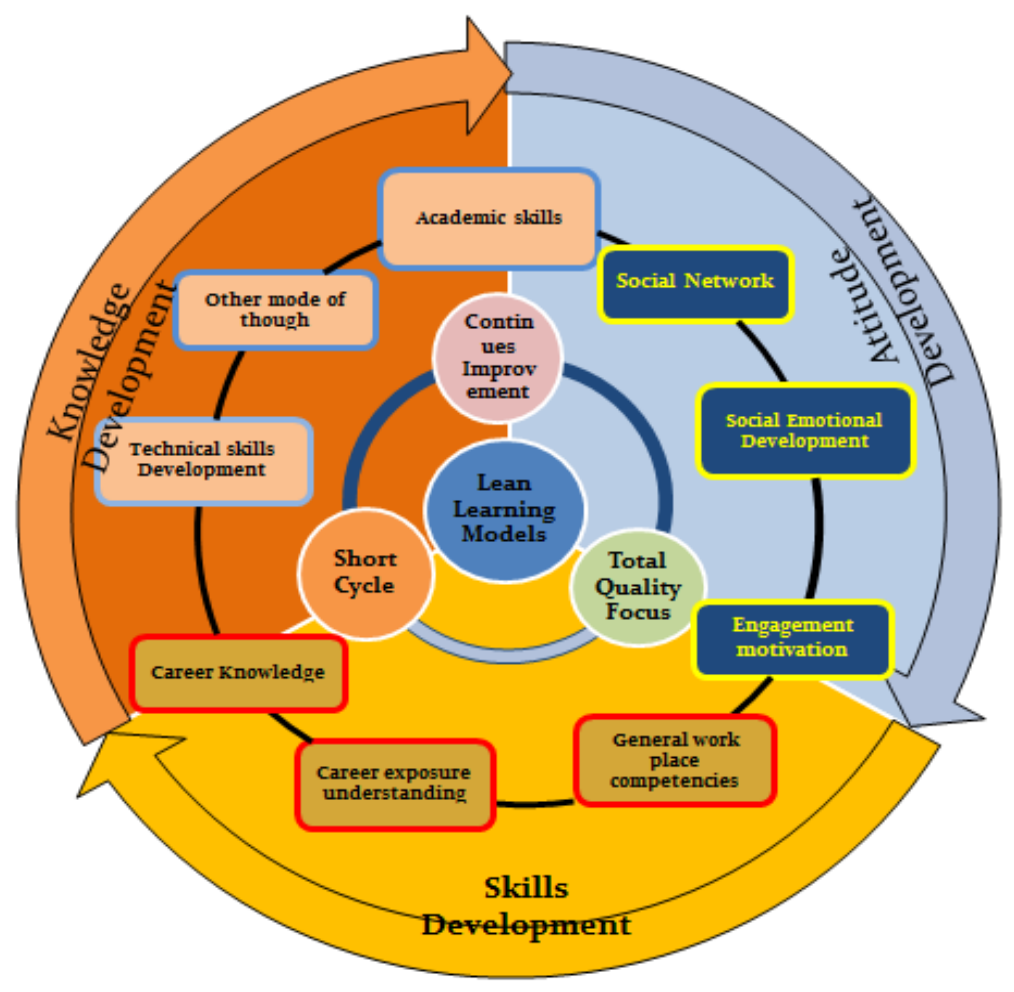

Figure 1. Learning Models Design

\section{Methodology}

This research is a research development $(\mathrm{R} \& \mathrm{D})$ using the modified design of Borg and Gall. It included four steps, i.e. 1) analyzing the product to be developed, 2) developing the initial product, 3) expert validation and revision, 4) field trials and products finalization. The outcomes of this research are the lean-based learning models that were tested in case of its validity, effectiveness, and practicality.

The research product had been through the tests of validity, effectiveness, and practicality. The validity test used content validity with the questionnaire completed by 5 selected experts based on the relevant expertise. The results of the validity test were presented descriptively. The effectiveness test of the learning model was done with experimental study with the populations and the samples were the eleventh-grade students of mechanical engineering from the vocational high school in Kepulauan Riau. The sample was selected through the random cluster sampling technique, i.e. the students who were carrying out industrial practices or internship with work shadowing strategies. The practicality tests were measured by analyzing the student learning outcomes after the action process.

\section{Results and Findings}

\subsection{The Validity Test Model}

Based on the results of the study, the Lean-based learning model has been tested its content validity based on 5 experts assessment. The model validity test referred to 3 assessment aspects, namely: 1) the supporting theory, 2) the structure of the learning model and 3) the learning outcomes. Those three aspects were described in the following items: a) the adequacy and accuracy of the theories to arrange the learning needs and the learning model development, $\mathrm{b}$ ) the concepts and teaching processes with the relevant learning strategies and techniques as the foundation of the learning models, c) the adequacy and accuracy of the relevant theories related to learning strategies to support the learning model, d) the background of the model development, e) the objectives of the model development, f) the model description, g) the reaction principles of the learning, h) the media system in learning, i). the supporting systems in learning, j) the use of learning approach, k) the learning steps, 1). the assessment technique, $\mathrm{m})$. the evaluation of assessment results, n) the proposed competency, o). the proposed learning outcomes. Based on the analysis results, the Lean-based learning models can be included in the «valid» category.

\subsection{The Effectiveness Test Model}

The effectiveness of the learning model was measured based on the learning outcomes among the vocational high school students at the end of industrial practices. They implemented the internship using the work shadowing strategy. The assessment results showed that the minimum completeness criteria were $60 \%$ with the individual 
completeness of 75. This assessment was carried out based on the average scores from both the teachers and the industrial instructors as the field supervisors. Referring to the students' learning outcomes, there were $80 \%$ of them who passed the completeness criteria with the category of «Good».

\subsection{The Practicality Test Model}

The practicality tests were done to the respondents consisting of the teachers who taught in mechanical engineering majors, the industrial instructors and the students who had applied the lean principles for their learning process in the industry. The practicality results were presented in the form of percentages. Based on the research, it was obtained that the teacher responses were $86 \%$, the instructors were $80 \%$ and the students were $84 \%$ respectively. It means the results of the practicality test can be considered as «Good».

The appropriate learning models will greatly influence the success of the teaching process. It includes the series of steps or often called "phases" to help the students to achieve the specific learning goals (Eggen.P;D.Kauchak, 2012)(Hartanto, 2017). The Lean-based learning model provides real experience by directly connecting the learning process with the experts of the working field in the Mechanical Engineering Department. This model can be called Work Integrated Learning (WIL), i.e. the educational activities that integrate academic learning of a discipline with its practical application in the workplace. This model is able to provide students with real work experience and present a bridge connecting the students' academic and the professional world of work. The leanbased learning model provides students with the opportunity to combine skills and theory of learning in school with direct application in the world of work (Estriyanto, 2017), (Robinson, 2010). The good learning experience will support students' competency and this is in line with the basic concept of vocational education. Moreover, this learning model becomes an effort to prepare and enhance students' ability to have work skills as vocational learning is a type of education to prepare students to work. Students must learn knowledge, skills, attitudes and do work in accordance with the rules and the real conditions of the world of work, afterwards the learning strategy must be directed according to the needs of the world of work, (Melo, 2013), (Hartanto et al., 2019).

\section{Conclusions}

Based on the research results, it can be concluded that the Lean-based learning model is considered valid, effective and practical to improve the work skills among vocational high school students ; as a result of the research this learning model is feasible to be implemented in vocational schools. Applying this model is very important because it is a way to integrate school learning with the world of professional work. This learning model makes vocational students get real work experience. Learning systems that integrate the world of work provide exceptional benefits in the development of vocational student work skills competencies.

\section{Acknowledgements}

This research was supported by the Ministry of Research, Technology and Higher Education of the Republic of Indonesia through the letter of decree No. 7/E/KPT/2019. Our gratitude also goes to Universitas Riau Kepulauan.

\section{REFERENCES}

[1] Blum, N. (2008). Environmental education in Costa Rica: Building a framework for sustainable development? International Journal of Educational Development, 28(3), 348-358. https://doi.org/10.1016/j.ijedudev.2007.05.008

[2] Calhoun, Calfrey.C;Finch, A. V. (1982). Vocational Education Concept and Operation (2nd ed.). California: Wadsworth Publishing Company.

[3] Chaturvedi, A., Yadav, A. K., \& Bajpai, S. (2011). Communicative Approach to Soft \& Hard Skills. Vsrdjournals.Com, l(1), 1-6. Retrieved from http://vsrdjournals.com/MBA/Issue/2011_3_March/1_Ajir _Chaturvedi_Research_Article_Mar_2011.pdf

[4] Coates, D. E. (2006). Hard skills vs soft skills . 1-3.

[5] Dillon, A. P. (1985). A Revolution in Manufacturing: The SMED System. Translated. Norwalk: Productivity Press.

[6] Eggen.P;D.Kauchak. (2012). Strategi dan Model Pembelajaran (6th ed.; S. Wahono, ed.). Jakarta.

[7] Estriyanto, Y. at al. (2017). The missing productive vocational high school teacher competency standard in the Indonesian education system. Journal of Technical Education and Training, 9(1), 26-44.

[8] Fagerlind .S, A. C., Gustavsson, M., .K, N., .J, G., \& Ekberg, K. (2015). Lean production tools and decision latitude enable conditions for innovative learning in organizations: A multilevel analysis. Applied Ergonomics, 47, 285-291. https://doi.org/10.1016/j.apergo.2014.10.013

[9] Feld, W. M. (2001). Lean manufacturing: tools, techniques, and how to use them. Washington, D.C: The St. Lucie Press/APICS Series on Resource Management.

[10] Furham, A. (2005). The Psychology of Behaviour at Work. the individual in the organization. (2nd, ed.). New York: Psychology Press.

[11] Habanabakize, T., \& Pardjono. (2018). The Competence of Graduates in Machining Technology Vocational High Schools Based on National Practical Exam in Yogyakarta, 
Indonesia. American Journal of Educational Research, Vol. 6, 2018, Pages 840-844, 6(6), 840-844. https://doi.org/10.12691/EDUCATION-6-6-38

[12] Hartanto, S. (2017). Need And Analysis Of Soft Skills For Students Of The Mechanical Engineering Department Of Vocational High School. International Journal of GEOMATE, 12(30).https://doi.org/10.21660/2017.30.tvet0 17

[13] Hartanto, S., \& Fordiana, R. (2018). Learning Needs Analysis of Vocational HighSchooì Chemical Subjects in Mechanical Engineering Department. In International Journal of Engineering \& Technology (Vol. 7). Retrieved from http://www.rsc.org/globalassets.

[14] Hartanto, S., Handoko, Arifin, Z., Huda, A., Fordiana, R., \& Yeni, N. (2019). Learning material analysis of motorcycle engine tune-up practice competency of vocational high school students. International Journal of Recent Technology and Engineering, 8(2 Special Issue), 166-171.

[15] Joyce, Bruce.R; Weil.M, E. . (2009). Models of Teaching (8th ed.). Boston: Pearson/Allyn and Bacon Publishers.

[16] Lubis, S. (2010). Concept and Implementation of Vocational Pedagogy In TVET Teacher Education. 1stUPI International Conference on Technical and Vocational Education and Training Bandung, Indonesia, (November), 165-173.

[17] Majid, S., Liming, Z., Tong, S., \& Raihana, S. (2002). Student reflection as a tool for assessing standards. International Electronic Journal for Leadership in Learning, 6(2), 1036-1042.

[18] Mangala Ethaiya Rani, S. (2010). Need and Importance of Soft Skills in Students. Journal of Literature, Culture and Media Studies, 2, 1-6.

[19] Melo, A. C. M. (2013). Life Skills Training Through Situated Learning Experiences: an Alternative Instructional Model. Journal of Chemical Information and Modeling, 53(9), 1689-1699. https://doi.org/10.1017/CBO978110741 5324.004

[20] Palmer, R. (2007). Skills for work?: From skills development to decent livelihoods in Ghana's rural informal economy. International Journal of Educational Development, 27(4), 397-420. https://doi.org/10.1016/J.IJ EDUDEV.2006.10.003

[21] Pritchard, J. (2013). The Importance of Soft Skills in EntryLevel Employment and Postsecondary Success: Perspectives from Employers and Community Colleges AUTHOR. 1-41.

[22] Robinson, K. K. (2010). 21St Century Knowledge and Skills in Educator Preparation. Education, (September), 40. https://doi.org/10.1787/9789264193864-en

[23] Robles, M. M. (2012). Executive Perceptions of the Top 10 Soft Skills Needed in Today's Workplace. Business Communication Quarterly, 75(4), 453-465. https://doi.org/10.1177/1080569912460400

[24] Rukun, K. at. a. (2015). Designing interactive tutorial compact disc (CD) for computer network subject. Jurnal Teknologi, 77(23). https://doi.org/10.11113/jt.v77.6682

[25] Sousa, D. A. (2001). Mind, Brain, and Education: The
Impact of Educational Neuroscience on the Science of Teaching. 38(1), 183-212.

[26] Sundar, R., Balaji, A. N., \& Satheesh Kumar, R. M. (2014). A review on lean manufacturing implementation techniques. Procedia Engineering, 97, 1875-1885. https://doi.org/10.1016/j.proeng.2014.12.341

[27] Syahmaidi.E, Hidayat.H, \& Hartanto.S.at.al. (2019). Needs analysis of designing online computer-assisted training to improve pedagogical competencies in engineering education. International Journal of Engineering and Advanced Technology, 8(6), 4619-4624. https://doi.org/10.35940/ijeat.F8905.088619

[28] Wilson, L. (2010). How to Implement Lean Manufacturing. New York: The McGraw-Hill Companies, Inc. 